\title{
ユニット型特別養護老人ホームの建設費と土地取得費の実態に関する研究 A STUDY ON THE COST OF CONSTRUCTION AND LAND ABOUT UNIT-TYPE SPECIAL NURSING HOME
}

\author{
佃一悠*, 井上由起子**, 西出和彦*** \\ Haruka TSUKUDA, Yukiko INOUE and Kazuhiko NISHIDE
}

\begin{abstract}
The purpose of this research is to clarify the cost of construction and land about typical unit-type special nursing home. An analysis was carried out by statics of questionnaire for institutions throughout Japan. The results are following.

1. The total floor area par bed was different on region, but the costs per square metre or bed were not different in this research. In change over the years, each were decreasing from 2003, and the costs per bed was influenced on the area per bed and the costs per area.

2. The costs of construction were covered by subsidy, their own money and loan on most institutions. Subsidy was decreasing from 2005, instead of loan was increasing. Their own money correlates with years from the establishment of corporation.

3. Most institutions purchaced land by their own money only or with loan. The costs in the 23-boroughs, Tokyo and an area designated for urbanization are about two or three times high than other areas.

4. The costs of both construction and land were covered by official subsidy, their own money and loan on $95.4 \%$ of institutions. In the establishment of institution with land acquisition and construction, subsidy and loan are needed.
\end{abstract}

Keywords: Unit-type special nursing home, Private room and multi-beds room, the cost of construction, the cost of land ユニット型特別養護老人ホーム, 個室と多床室, 建設費, 土地取得費

\section{1. 研究概要}

\section{1. 背景}

2003 年、ユニット型特別養護老人ホーム（以下、ユニット型特養） は制度化され、新設の特養は原則としてユニット型が建設されるこ ととなった。ユニットケアは「施設の居室をいくつかのグループに 分けて、それぞれをひとつの生活単位とし、少人数の家庭的な雰囲 気のなかでケアを行うもの」と定義されており注1)、ユニット型特着 は「住まい」としての質を重視した、ユニットケアをおこなうため の特養で、居室が個室であることと生活単位ごとに 10 名程度のまと まりでユニット化されている点が特徴としてあげられる。制度化以 前の特養は、ホスピタルモデルを踏襲し、集団処遇を前提とした収容、 保護施設としての意味合いが強かったが、1990 年代以降、多床室か ら個室へ、集団ケアから個別ケアへといった居住の場としての試み が見られるようになった。さらに建築計画分野における一連の研究 の成果もあり、2003 年の制度化に至った。2005 年には居住費（ホテ ルコスト）が自己負担化され、建設費の多くを国庫補助金で賄う時 代から、交付金額が削減されて、地方自治体による交付金、自己資金、 借入金によって建物を整備し、居住費で回収する方法に変更になっ た主2)。個室ユニットケアでよりよいケアがおこなわれるためには、 適正な職員配置と職員給与が不可欠であり、建設費を一定範囲に抑
え、開設後の収支に影響を与える借入金を低減することが重要となっ てくる。このように、現在では経営的な視点も含めて建物整備を考 える必要が出てきている。

最近の動きとして、2010 年 9 月には、「特別養護老人ホームの整備 及び運営に関する基準」の一部が改正され注3)、ユニット個室の床面 積の最低基準は $13.2 \mathrm{~m}^{2}$ から $10.65 \mathrm{~m}^{2}$ に緩和された。個室化を原則と しながらも、従来より面積を抑えることで、建設費を抑えることが 可能となった。さらに、2012 年 4 月には介護報酬の改定がおこなわれ、 多床室と個室では入居者 1 人あたりの職員配置に差があることを踏 まえて、報酬を適正化するとともに、低所得者の利用者負担注 4) を軽 減することが決定され、ユニット型個室の更なる整備推進の方針が 示されている注5)。

\section{2. ユニット型特養に関する先行研究}

1990 年代から、特養では全室個室など様々な試みがみられるよう になった。外山らは、個室化 ${ }^{4,5)}$ 、段階的な空間構成 ${ }^{6)}$ 、個別ケア ${ }^{7)}$ 等に関する研究をおこない、これらの成果が 2003 年の制度化に結実 した。制度化以降、ユニット型特養に関する研究として、毛利ら ${ }^{8)}$ は制度化開始年度に開設された施設を対象とし、平面計画特性とケ ア体制を踏まえて空間の傾向を明らかにした。董ら ${ }^{9)}$ は同様に制度
* 東北大学大学院丁学研究科都市・建築学専攻 助教・博士 (工学)

** 日本社会事業大学専門職大学院 准教授 ·博士 (工学)

*** 東京大学大学院工学系研究科建築学専攻 教授・博士(工学)
Assist. Prof., Dept. of Architecture and Building Science, Grad. School of Eng., Tohoku Univ., Dr. Eng.

Assoc. Prof., Japan College of Social Work, Dr. Eng.

Prof., Dept. of Arch., School of Eng., Univ. of Tokyo, Dr. Eng. 
化後普及期における施設の傾向を明らかにしている。橘 ${ }^{10)}$ はケアの 方針や環境等が入居者の滞在場所に影響を与えていることを指摘し た。松原ら ${ }^{11)}$ は老人保健施設と比較し、職員のユニット内滞在状況 と職員体制に関係があることを明らかにしている。石井 ${ }^{12)}$ は夜勤時 の介護や空間利用の実態を明らかにし、空間構成による違いを指摘 している。

介護経営の分野では、毛利ら ${ }^{13)}$ が人材育成の視点から介護職員の 属性や業務の実態把握をおこない、制度上の業務規定の必要性を指 摘している。井上 ${ }^{14)}$ は、ユニット型と従来型の建物整備および法人 経営についての比較からユニット型推進における課題について考察 している。藤井ら ${ }^{15)}$ は、介護老人福祉施設の財務諸表の分析から、 財務行動の傾向を明らかにし、再生産コストの議論に関する示唆を 与えている。

\section{3. 研究の目的}

ユニット型特養の先行研究としては、利用者の生活の視点、職員 の動きと利用者の生活との関係性といった観点からの蓄積がみられ る。また、近年、建物整備や再生産コストについての議論もみられ るようになってきたが、全国的な建設費や土地購入費の実態につい ては、まだ十分に明らかにされていない。

日本医療福祉建築協会の報告書 ${ }^{16)}$ によれば、一床あたり面積の 平均は、ユニット型特養では $60.37 \mathrm{~m}^{2}$ 、従来型特養では $50.66 \mathrm{~m}^{2}$ 、 坪単価の平均は、ユニット型特養では 725.6 千円、従来型特養で は995.7 千円、一床あたり建設単価の平均はユニット型特養では 13, 129.7 千円、従来型特養では 15, 252.6 千円であることが示され ている主6)。建設単価については、建設年での変化を考慮する必要が あるが、居住費の 6 万円と 1 万円に匹敵する差ではないことが明ら かであると思われる。しかし、限られた物件を対象としているため、 経年的な傾向はつかめておらず、あわせて土地価格の実態について も明らかになっていないため、経年変化を踏まえたより広範なデー タの把握が必要である。

本研究では、ユニット型施設として建設された特養を対象とし、 建設費および土地購入費の実態を明らかにすることを目的としてい る。

\section{2. 調査概要}

\section{1. 調査対象}

ユニットケアを実践する 3,344 施設に対し、郵送によるアンケー 卜調査をおこなった注7)。アンケートは認知症介護研究・研修東京セ ンターによって、ユニットケア実践施設の運営実態把握のためおこ なわれたが、ここではその中から建物整備に関わる部分のみについ て分析をおこなった。厚生労㗢省の「平成 20 年介護サービス施設・ 事業所調查結果の概況」によると、平成 20 年度に全国でユニットケ アをおこなっているユニット型および一部ユニット型施設は、特養 で 1,630 施設、老健で 286 施設の計 1,916 施設であった。今回の調 查対象にはユニット型施設に加え、ユニットケアをおこなう従来型 施設も含まれているため、調查対象数の方が大きくなっている。ア ンケートは、2009年 11 月 30 日に配布、2010 年 1 月 8 日までに 1,008 施設の調查票を回収し、回収率は $30.14 \%$ であった（表 1 )。

\section{2. 分析対象}

図 1 に分析対象の絞り込みの経緯を示す。まず、回答があった 1,008 施設から特養 871 施設のみを抽出した注8)。次に、特養のうち新築・ 改築によって建設された 564 施設を抽出し、そのうち居室が全室個 室である 546 施設を分析対象とした。

\section{3. 分析方法}

分析は統計的手法によりおこない、各データの外れ值検定には、 Tukey 法を用いた。まず、一床あたり延床面積の外れ值検定をおこな い、外れ值を除くとともに、 $35 \mathrm{~m}^{2} /$ 床未満のデータとなる施設を除 いた。この際除いた施設は一床あたり建築単価、面積あたり建築単 価の分析においても除くこととした。これは、既往研究注9)では、一 床あたりの延床面積が $35 \mathrm{~m}^{2}$ / 床未満の施設はわずかしか報告されて おらず、あまりにも施設規模の小さい施設は一般的な施設ではなく、 記載ミスと判断できるためである。全体の概要を見る際には通所介 護併設施設も含めたデータを用いるが、それ以外では主に併設施設 を除き、分析をおこなう。

また、本研究における建設費は、土地代を除き、土地造成費、器 具及び備品収得費を含んでいる注10)。

\section{3. 調査結果}

\section{1. 調査対象施設の特性}

\section{（1）立地や規模からみた母集団の位置づけ}

表 2 に分析対象としたユニット型施設の概要を示す。開設年別施 設数では、2005 年が 110 施設と最も多く、2004 年から 2008 年に開 設された施設が大半を占める。地方区分では、中部地方が 150 施設 と最も多く、ついで関東地方が多い。四国、北海道に関しては 20 施 設に充たない。報酬地域区分注11)では、その他の地域の施設が最も 多く、全体の 8 割近くを占めており、東京 23 区にあたる特別区で は 11 施設であった。都市計画上の地域区分では、回答した施設のう ち、市街化区域、市街化調整区域、非線引き都市計画区域の順に多 い。定員数では、約 3 割の施設が $60 \sim 79$ 人で最も多く、次に 30 〜 59 人と $80 \sim 99$ 人の施設が同程度であり、それより定員が多くまた

表 1 調査概要

\begin{tabular}{|l|l|}
\hline 調査期間 & 2009 年 11 月 30 日〜 2010 年 1 月 8 日 \\
\hline 調査対象 & $\begin{array}{l}\text { ユニットケアを実践するユニット型施設および従来型施設 } 3,444 \\
\text { 施設 }\end{array}$ \\
\hline 調查方法 & 郵送によるアンケート調査 \\
\hline 調査内容 & $\begin{array}{l}\text { 1. 法人概要（施設の設置県、報酬地域区分、法人種別等） } \\
\text { 2. 施設概要（施設立地、施設種別、ユニット型施設としての開 } \\
\text { 設状況、施設およびユニット型の開設年、併設事業所、定員、職 } \\
\text { 員配置、延床面積、建設費、地購入費等) } \\
\text { 3. 経営実態 (平成 20 年度の事業活動計画書内容) }\end{array}$ \\
\hline $\begin{array}{l}\text { 回収数 / } \\
\text { 回収率 }\end{array}$ & 1,008 施設 $/ 30.4 \%$ \\
\hline
\end{tabular}

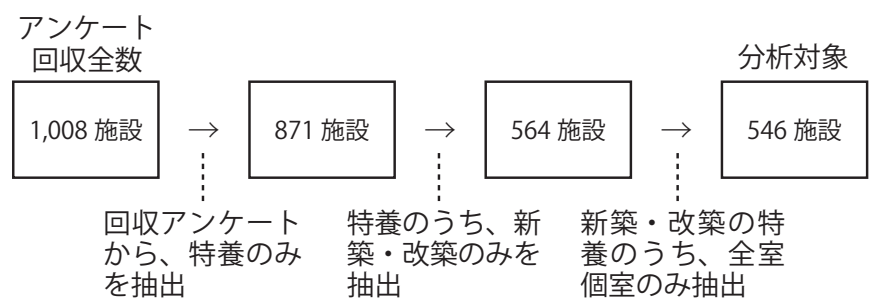

図1 分析対象絞り込み経緯 
は少なくなるほど施設数が減少している。

平成 21 年度の全国の介護老人福祉施設の実態注 ${ }^{12)}$ では、定員が 30 〜 59 人の施設が全体の $44.5 \% 、 60$ ～ 79 人の施設は $16.5 \%$ であり、 ユニット型特養は全体に比べて若干高い定員数に多く分布しており、 また 29 人以下の施設の割合が高い。

\section{（2）経営指標からみた母集団の位置づけ}

ここでは、事業活動収支から母集団の特性を確認する。表 3 は独 立行政法人福祉医療機構注 13$)$ の経営分析参考指標「平成 21 年度特別 養護老人ホームの経営状況」に記載されている平成 20 年度のユニッ 卜型特養と、本研究で対象とした施設のうち、収支の有効回答が得 られた 342 施設の事業活動収入に対する事業活動支出の割合を示し ている。

比較すると人件費と経費は同程度の割合を占めており、経営状況 を示すデータとしては妥当であると考えられる。減価償却費は若干 異なるが、これは、交付金が多く、減価償却費を低く抑えることが 可能であった時期の影響を受けているためと考えられる。

\section{2. 単位あたり面積および建設費}

\section{(1) 概要}

図 2 に一床あたり建設費、一床あたり面積、面積あたり建設費の 関係を示す。一床あたり建設費 $($ 円 / 床 $)=$ 一床あたり面積 $\left(\mathrm{m}^{2} /\right.$ 床 $)$ ×面積あたり建設費（円/床）であるため、建設費の削減には、延 床面積の縮減と、建設単価の低減の二つの手法があることがわかる。

図 3 に一床あたり建設費、面積あたり建設費、一床あたり面積の 外れ值を除いた分布を示寸。

一床あたり面積の平均值は $53.98 \mathrm{~m}^{2} /$ 床で、 $35.27 \sim 80.02 \mathrm{~m}^{2} /$ 床 の間に分布し、標準偏差は $9.23 \mathrm{~m}^{2} /$ 床、変動係数は 0.173 である。

面積あたり建設費の平均值は、239.22 千円 / $\mathrm{m}^{2}$ で、133.28〜 366.85 千円 / $\mathrm{m}^{2}$ の間に分布し、標準偏差は 42.59 千円 / $\mathrm{m}^{2} 、$ 変動係 数は 0.178 である。

一床あたり建設費の全国平均は 12,962 千円/床で、7, 302 19,474千円/床の間に分布し、標準偏差は 2,531 千円 / 床、変動係 数は 0.199 である。

それぞれの平均值を前述した日本医療福祉建築協会の報告書の值 と比較すると、一床あたり面積および一床あたり建設費については 本研究の方が小さい值を示した。面積あたり建設費については、本 研究の方が大きい值を示したが (一坪 $=3.3 \mathrm{~m}^{2}$ で計算)、土地造成費、 器具および備品収得費を含むためと考えられる。

\section{（2）地域別特性}

表 4 に全国平均值（「通所介護併設なし」施設のみ）を示す。併設 施設を含めた場合より、いずれも若干值が小さくなっている。

図 4 にエリア区分別の平均值を示す。一床あたり面積では、関東 が $49.8 \mathrm{~m}^{2} /$ 床、近畿が $49.7 \mathrm{~m}^{2} /$ 床といずれも $50 \mathrm{~m}^{2} /$ 床をわずかに 下まわる。それ以外は $54.0 \mathrm{~m}^{2}$ 以上であり、最も大きい北海道で 57.3 $\mathrm{m}^{2} /$ 床であった。関東・近畿では都市部の土地価格の高さが影響し ていることが考えられる。

面積あたり建設費では、4 件ではあるが北海道が最も高い 263.0 千 円 / $\mathrm{m}^{2}$ であった。ついで、近畿 250.5 千円 / $\mathrm{m}^{2}$ が高いが、四国、九
表 2 母集団の概要 $(n=546)$

a. 開設年別施設数

\begin{tabular}{|l|c|c|c|c|c|c|c|c|c|c|c|}
\hline 開設年 & $\begin{array}{c}2002 \\
\text { 以前 }\end{array}$ & 2003 & 2004 & 2005 & 2006 & 2007 & 2008 & 2009 & 2010 & 未回答 & 総計 \\
\hline 施設数 & 34 & 25 & 70 & 110 & 83 & 95 & 82 & 36 & 8 & 3 & 546 \\
\hline 割合 $(\%)$ & 6.2 & 4.6 & 12.8 & 20.1 & 15.2 & 17.4 & 15.0 & 6.6 & 1.5 & 0.5 & 100 \\
\hline
\end{tabular}

b. エリア区分別施設数

\begin{tabular}{|c|c|c|c|c|c|c|c|c|c|c|}
\hline 地方 & 北海道 & 東北 & 関東 & 中部 & 近畿 & 中国 & 四国 & 九州 & 不明 & 総計 \\
\hline 施設数 & 18 & 74 & 124 & 150 & 80 & 33 & 14 & 43 & 10 & 546 \\
\hline 割合 (\%) & 3.3 & 13.6 & 22.7 & 27.5 & 14.7 & 6.0 & 2.6 & 7.9 & 1.8 & 100 \\
\hline
\end{tabular}

C. 報酬地域区分別施設数

\begin{tabular}{|c|c|c|c|c|c|c|}
\hline 報酬区分 & 特別区 & 特甲地 & 甲地 & 乙地 & その他 & 総計 \\
\hline 施設数 & 11 & 56 & 20 & 67 & 392 & 546 \\
\hline 割合 (\%) & 2.0 & 10.3 & 3.7 & 12.3 & 71.8 & 100 \\
\hline
\end{tabular}

d. 都市計画上の地域区分別施設数

\begin{tabular}{|c|c|c|c|c|c|}
\hline 地域区分 & 市街化区域 & $\begin{array}{c}\text { 市街化調整 } \\
\text { 区域 }\end{array}$ & $\begin{array}{c}\text { 非線引き都 } \\
\text { 市計画区域 }\end{array}$ & 未回答 & 総計 \\
\hline 施設数 & 176 & 140 & 90 & 140 & 546 \\
\hline 割合 $(\%)$ & 32.2 & 25.6 & 16.5 & 25.6 & 100 \\
\hline
\end{tabular}

e. 定員別施設数

\begin{tabular}{|c|c|c|c|c|c|c|c|}
\hline 定員数 & $\sim 29$ 人 & $30 \sim 59$ 人 & $60 \sim 79$ 人 & $80 \sim 99$ 人 & $100 \sim 119$ 人 & 120 人 & 総計 \\
\hline 施設数 & 46 & 100 & 181 & 102 & 84 & 33 & 546 \\
\hline 割合 $(\%)$ & 8.4 & 18.3 & 33.2 & 18.7 & 15.4 & 6.0 & 100 \\
\hline
\end{tabular}

表 3 平成 20 年度事業活動収入に対する事業活動支出の割合（\%)

\begin{tabular}{ccc}
\hline & 福祉医療機構 & 本研究 \\
\hline 人件費 & 56.0 & 55.3 \\
経費 & 27.7 & 27.4 \\
減価償却費 & 8.0 & 11.5 \\
その他 & 0.7 & 1.5 \\
収支差額 & 7.6 & 4.2 \\
\hline 合計 & 100 & 100
\end{tabular}

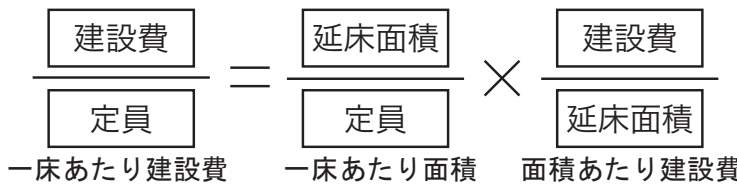

図 2 一床あたり建設費，一床あたり面積，面積あたり建設費の関係
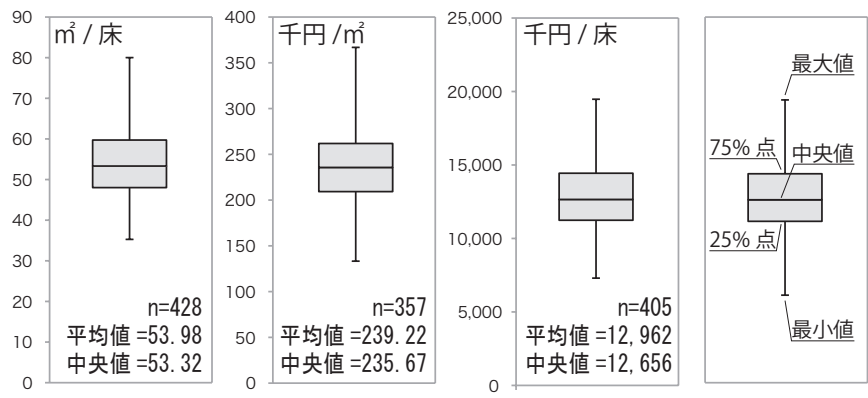

a. 一床あたり面積 b. 面積あたり建設費

c. 一床あたり建設費

凡例
表 4 単位あたり面積および建設費の全国平均值

\begin{tabular}{ccc}
\hline & 有効回答数 & 平均値 \\
\hline 一床あたり面積 & 168 & $53.39 \mathrm{~m}^{2} /$ 床 \\
面積あたり建設費 & 147 & 238.97 千円 $/ \mathrm{m}^{2}$ \\
一床あたり建設費 & 164 & 12,745 千円 / 床 \\
\hline
\end{tabular}


州は 205 千円 / $\mathrm{m}^{2}$ 前後であり、他地域との差が大きい。

一床あたり建設費では、北海道が 15, 107 千円 / 床と最も大きく、 四国が 11, 324 千円/床と最も小さい。関東は四国、九州に続いて小 さく、11,839 千円/床であった。

一床あたり面積および面積あたり建設費を説明変数、一床あた り建設費を目的変数として重回帰分析をおこなうと、標準偏回帰 係数は一床あたり面積が $0.686(\mathrm{P}=0.0013)$ 、面積あたり建設費が $0.920(\mathrm{P}=0.003)$ で面積あたり建設費の影響の方が大きい。

\section{(3) 経年変化}

図 5 に施設開設年による平均值の変化を示す。一床あたり面積では、 2003 年が最も大きく、徐々に減少している。制度化された 2003 年頃 には潤沢な公的補助金があったが、その後の減少が影響していると 考えられる。また、ホテルコストが導入されたことによって、建設 費と経営を意識した施設が増えてきたことも推察される。

面積あたり建設費では、2004 年以降 2008 年の 232.1 千円 / $\mathrm{m}^{2} ま$ で下降傾向にあったが、2009 年では 240.3 千円 / $\mathrm{m}^{2}$ と若干増加し、 2010 年も同程度で推移している。

一床あたり建設費では、2003、2004 年が約 14, 500 千円/床で最

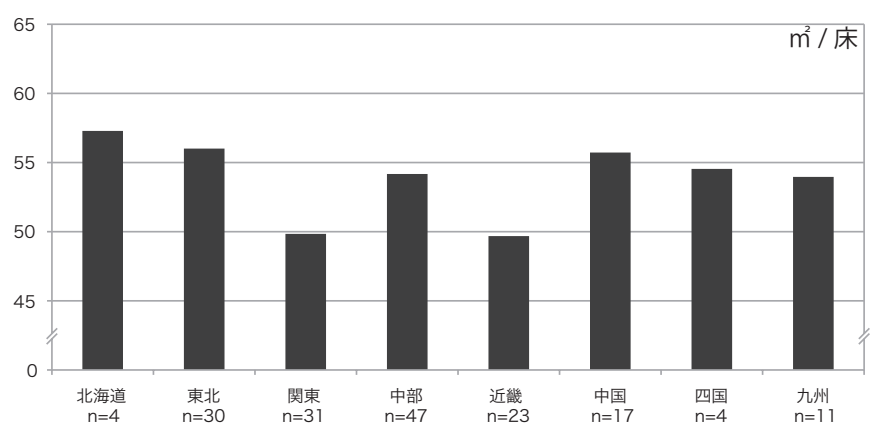

a. 一床あたり面積（通所併設施設除く） (n=167)

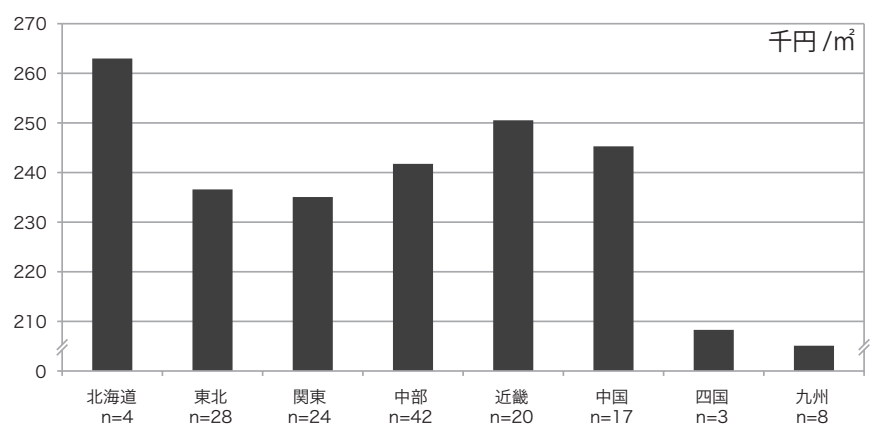

b. 面積あたり建設費（通所併設施設除く）（n=146）

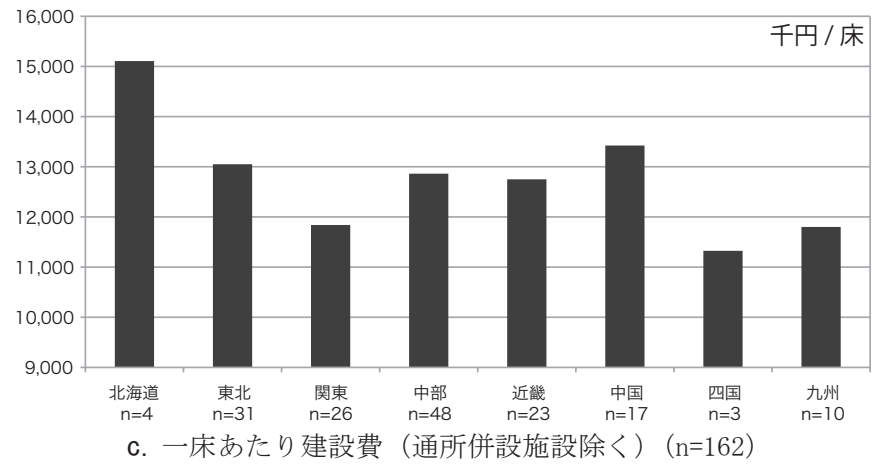

図 4 単位あたり面積および建設費の地方区分別実態
も高い。2005 年に約 2, 000 千円 / 床減少し、2009 年まで同程度で 推移している。2 事例のみだが 2010 年には 9, 476 千円 / 床と、再 度大きく減少している。同様に重回帰分析をおこなうと、標準偏回 帰係数は一床あたり面積が $0.944(\mathrm{P}=0.0001)$ 、面積あたり建設費が $0.315(\mathrm{P}=0.0284)$ で一床あたり面積の影響の方が大きい。

\section{(4) 小結}

一床あたり面積および面積あたり建設費については、変動係数に 大きな差はなく、双方による縮減が理論上可能である。

ただし、エリア区分別に見ると、面積縮減の可能性は面積がすで に縮減している関東や近畿よりもそれ以外で大きい。面積あたり建 設費は地域によって異なると一般には言われているが、本調查結果 では明らかにはならなかった。日本医療福祉建築協会の報告書でも 同様であった。

経年変化を見ると、一床あたり面積は 2003 年が最も大きく、徐々 に減少しており、公的補助金の額が影響していると考えられる。面 積あたり建設費は、年によって変動がみられる。一床あたり建設費 は双方の影響を受け、一床あたり面積と同様に 2003 年以降減少しつ つ、面積あたり建設費の影響を受け局所的な増減がみられる。

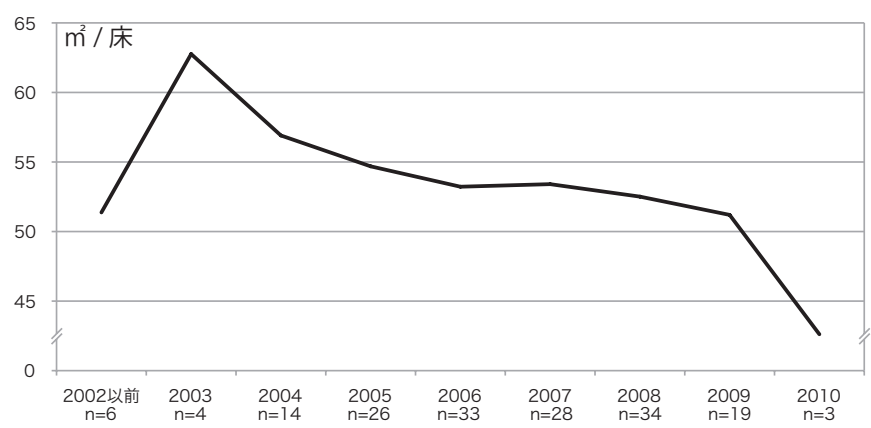

a. 一床あたり面積（通所併設施設除く）（n=167）

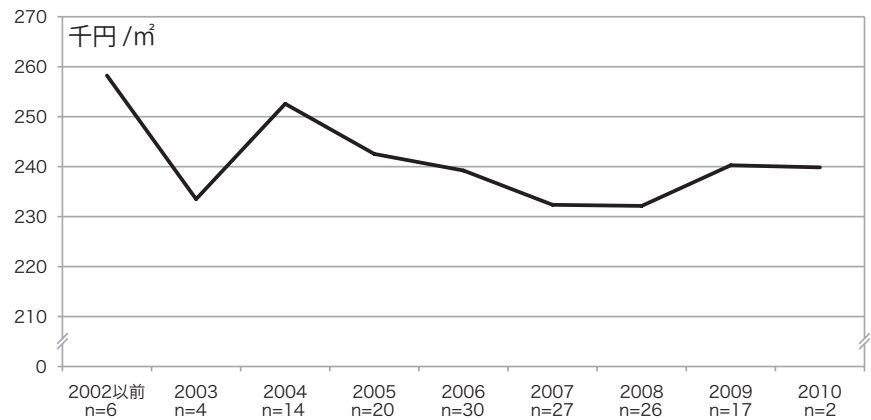

b. 面積あたり建設費（通所併設施設除く）（n=146）

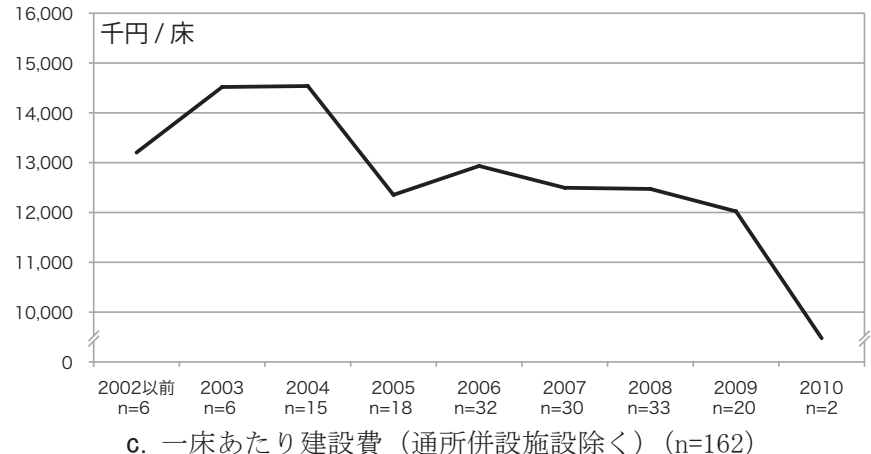

図 5 単位あたり面積および建設費の施設開設年別実態 


\section{3. 建設費の資金調達}

\section{（1）資金調達状況}

表 5 に公的補助金の経年変化と建設費の資金調達方法の考え方 を示寸。建設費は公的補助金、自己資金、借入金で賄われている。 2004 年度以前は補助金が潤沢で、多くを占めていたが、2005 年以降 大きく削られ、一床あたり約 200 万円となった。2009 年から 2011 年 には、緊急整備として増額されている。図 6 に、建設費総額と自己 資金、借入金、公的補助金の内訳について回答のあった 263 施設を 対象とし、その資金調達の状況を示す。約 9 割の施設が自己資金、 借入金、公的補助金全てを利用して建設している。また、公的補助 金と借入金のみで建設している施設も 20 件みられた。

\section{（2）一床あたり建設費の平均値と資金調達方法の内訳}

図 7 に、自己資金、借入金、公的補助金を利用し建設された 234 施設のうち、通所介護併設施設を除く 89 施設の一床あたり平均建設 費の内訳を示す。内訳は 89 施設の平均値によって算出した。

建設費の平均值は 12,687 千円/床であり、 $57.9 \%$ を借入金が占める。 次いで、29.2\%を公的補助金が占め、自己資金は $12.9 \%$ であった。

\section{(3) 一床あたり建設費およびその内訳の経年変化}

建築年数が不明な 1 施設を除き、建設年ごとの建設費とその内訳 を図 8 に示す。総建築費は 2004 年が高いが、全体として 12,000 千 円/床前後を推移している。公的補助金の割合は、2005 年以降、徐々 に減少しており、特に 2008 年以降は著しい。一方、自己資金は 2,000 千円 / 床以下で推移しており、公的補助金の減少分は借入金の増加 によって補われている様子が伺える。2010 年はそれまでに比べて金 額の減少が著しいが、1 件のみで分析に適さないため今回は除いた。

\section{（4）一床あたり自己資金}

図 9 に自己資金の分布を示す。分布の幅が広く、施設の資金力によっ て自己資金比率に差があることがわかる。また、図 10 に法人開設か らの年数ごとの一床あたり自己資金の平均值を示す。法人開設から 年数が経つほど自己資金の額は大きくなっている。施設開設以前の 事業で内部留保があり、それを利用していると推察される。

\section{(5) 小結}

公的補助金の削減に伴い、2005 年以降は建設費に占める公的補助 金の割合が減少しており、変わって借入金の割合が増加している。

表 5 公的補助金の経年変化と建設費の資金調達方法の考え方

\begin{tabular}{|c|c|c|c|c|c|c|}
\hline 年度 & \multicolumn{2}{|c|}{2004 年度以前 } & & \multicolumn{2}{|c|}{$2005 ２ 008$ 年度 } & 2009 ～ 2011 年度 \\
\hline \multirow{5}{*}{$\begin{array}{l}\text { 資金 } \\
\text { 調達 }\end{array}$} & \multirow{4}{*}{$\begin{array}{l}\text { 公 } \\
\text { 的 } \\
\text { 補 } \\
\text { 助 } \\
\text { 金 }\end{array}$} & \multirow{2}{*}{\begin{tabular}{|l|} 
自己資金 \\
借入金 \\
\end{tabular}} & & 自己資金 & & 自己資金 \\
\hline & & & \multirow{2}{*}{\multicolumn{2}{|c|}{ 借入金 }} & & 借入金 \\
\hline & & 補助金 & & & & \\
\hline & & & & 交付金 & & 交付金 \\
\hline & \multicolumn{2}{|c|}{ 国による補助金 } & \multicolumn{3}{|c|}{$\begin{array}{l}\text { 三位一体の改革により } \\
\text { 地方自治体にる交付 } \\
\text { 金とな減額 }\end{array}$} & 緊急整備として増額 \\
\hline 制度 & \multicolumn{3}{|c|}{$\begin{array}{l}\text { 社会福祉施設等施設整 } \\
\text { 備費補助負担金 }\end{array}$} & \multicolumn{2}{|c|}{$\begin{array}{l}\text { 地域介護・福祉空間整 } \\
\text { 備等交付金 }\end{array}$} & $\begin{array}{l}\text { 地域介護·福祉空間整備等交付金, } \\
\text { 介護基盤緊急整備等踄時特例基金 }\end{array}$ \\
\hline 金額 & \multicolumn{3}{|c|}{\begin{tabular}{|l} 
社会福祉法人が設置す \\
る施設に対し、県負担 \\
$3 / 4$ 、国庫負担 $2 / 3$
\end{tabular}} & \multicolumn{2}{|l|}{ 約 200 万円 } & 350 ～ 400 万円 \\
\hline
\end{tabular}

借入金は開設後の経営に影響を与えることから、自己資金比率を増 加させることが重要となるが、自己資金は法人開設からの年数に相 関がみられる。

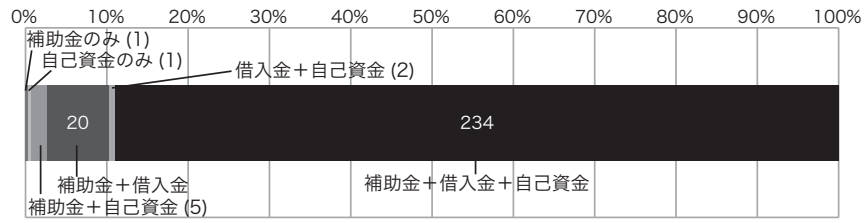

図 6 建設費の資金調達状況（n=263）

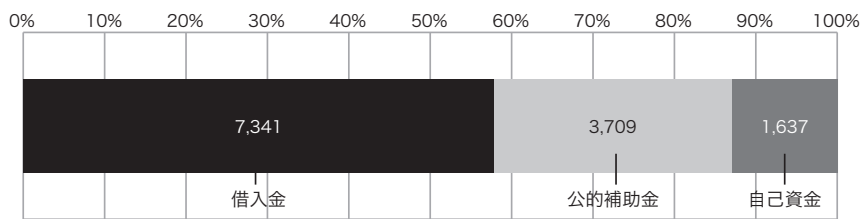

図 7 一床あたり平均建設費の内訳（千円 / 床）（n=89）

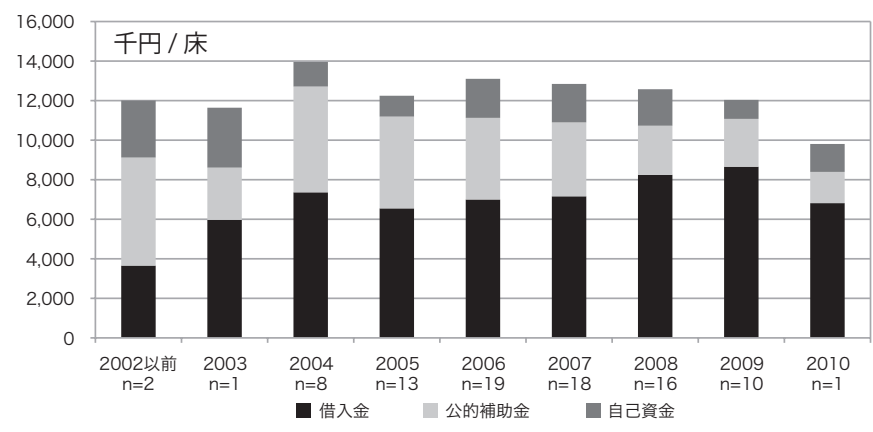

図 8 建設年別一床あたり建設費と内訳（通所併設施設除く）（n=88）

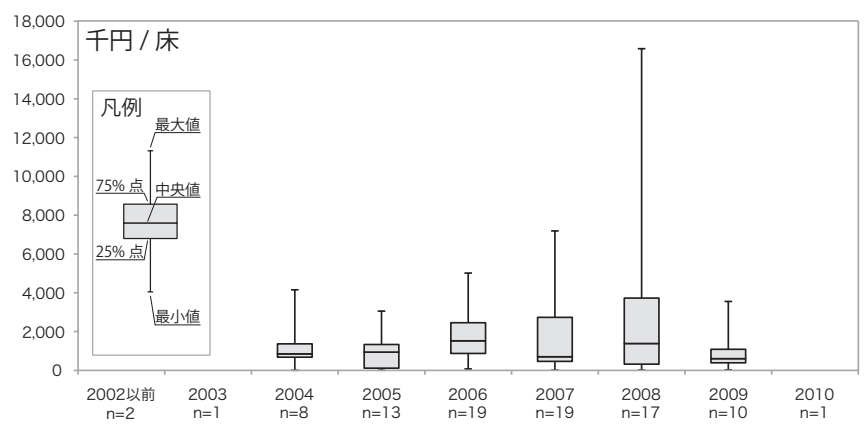

図 9 建設年別一床あたり自己資金 $(n=88)$

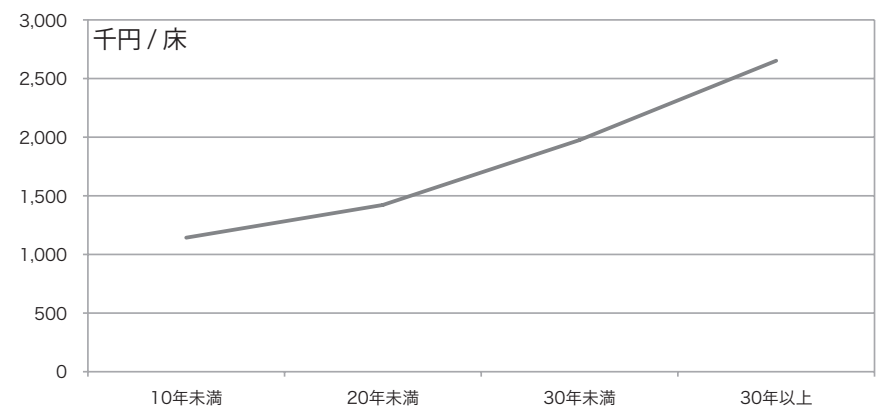

図 10 法人開設からの年数別一床あたり自己資金 $(n=88)$ 


\section{4. 土地購入費の資金調達 \\ (1) 土地取得方法による分類}

図 11 に土地取得方法の内訳を示す。回答のあった 298 施設のうち、 66. 1\%にあたる 197 施設が購入により土地を取得している。貨貸によ る土地取得は $24.2 \%$ 、若干数だが購入と賃貸を併用している例もみ られた。図 12 に購入、賃貸いずれか一方で取得した場合の都市計画 上の地域区分別、報酬地域区分別の状況を示す。都市計画上地域区 分では、購入が市街化区域では $64.8 \%$ と最も低く、市街化調整区域 (73. 1\%)、非線引き都市計画区域 $(79.5 \%)$ の順に購入の割合が高くなっ ている。市街化区域と市街化調整区域では購入の金額は同程度であ るが、市街化区域の方が賃貸の数が多い。しかしながら、報酬地域 区分別でみると、特別区（東京 23 区を指す）では 8 施設すべてが購 入により取得している。東京都は地価の高さを考慮して土地購入に 交付金を出しており注 ${ }^{14)}$ 、そのことが影響していると考えられる。他 の地域では、購入による取得は 60 〜 80\% 程度であった。

\section{（2）資金調達状況}

図 13 に土地購入した施設のうち、土地取得費と自己資金、借入金、 公的補助金の内訳について回答のあった 185 施設を対象とし、その 資金調達の状況を示す。自己資金のみの施設が最も多く、次いで自 己資金と借入金を利用した施設、借入金のみの施設である。土地購 入については、東京都の例を除いて、原則公的補助金の仕組みがな いため、公的補助金の利用はほとんどみられず、土地取得は自己資 金か借入金のいずれかによっている。

\section{（3）一床あたり土地購入費}

185 施設の土地購入費の平均值は、1, 675 千円/床であった。図 14 に都市計画上の地域区分別、報酬地域区分別の一床あたり購入費金 額の平均を示寸。都市計画上地域区分では、市街化区域が 2, 105 千 円/床と最も高く、順に低くなっており、非線引き都市計画区域に 比べて市街化区域は 2 倍近い金額が必要である。また、報酬地域区 分別にみると特別区が 4, 656 千円 / 床で最も高く、順に低くなって いる。乙地、その他と比べると特別区は 3 倍以上の金額が必要となっ ており、地域差は建設費に比心゙、土地取得費でより顕著である。

\section{(4) 小結}

土地取得には購入と賃貸の 2 つの方法が考えられるが、全体的に 土地購入の方が多い傾向がある。しかし、市街化区域では他の地域 に比べ土地購入の割合が低い。ただし、特別区では全て購入により 土地取得しており、自治体による交付金の影響が考えられる。

購入に限って土地取得費の調達方法をみると、自己資金が最も多 くみられ、借入金を利用している施設も多く見られた。実際の土地 購入費をみると地域差が大きく、特別区、市街化区域は他の地域に 比べ高い。都心で開設する場合には、購入費の調達のために高額な 借入金が必要となってくるため、交付金等の補助制度がない場合、 開設後の経営を圧迫していることが推察される。

\section{5. 建設費と土地購入費の資金調達 \\ （1）資金調達状況}

3. 3、3.4 では建設費と土地購入費それぞれについて、資金調達の

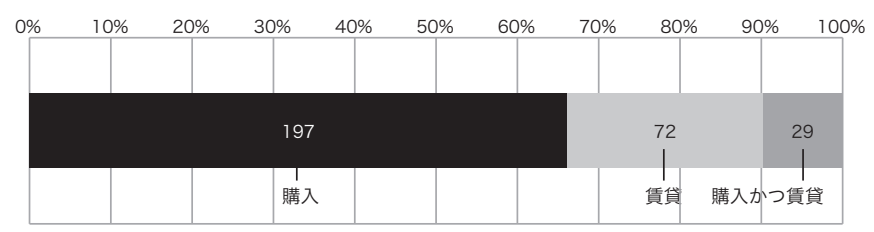

図 11 土地取得方法の内訳 $(\mathrm{n}=298)$
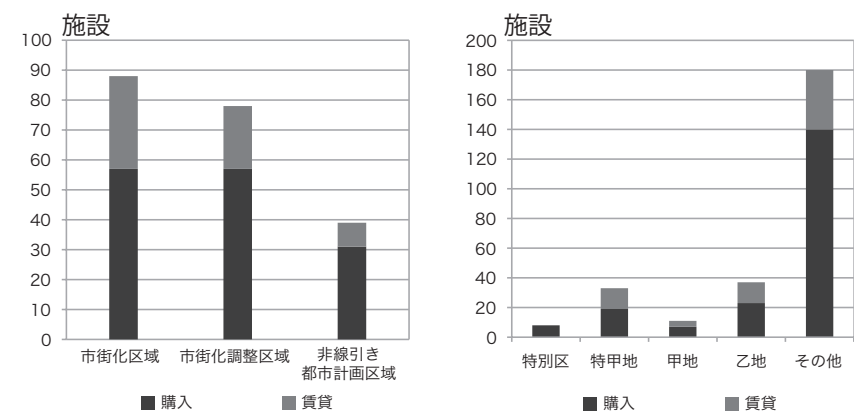

a. 都市計画上の地域区分別 $(\mathrm{n}=205)$ 図 12 土地取得方法
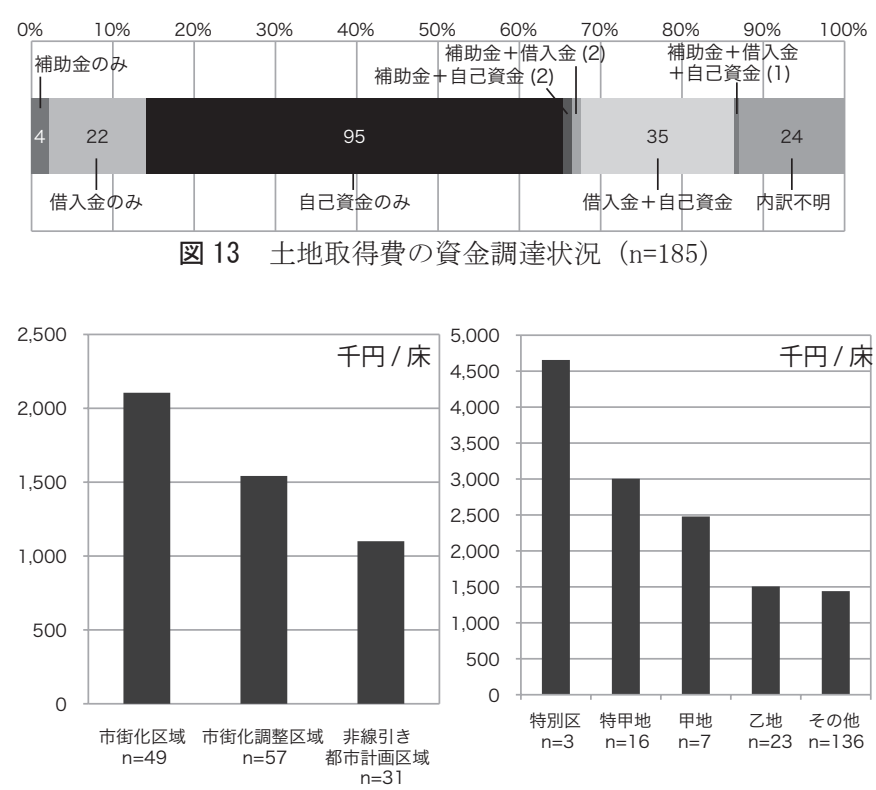

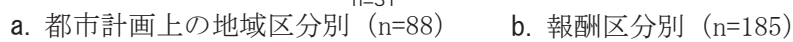

図 14 一床あたり土地購入費

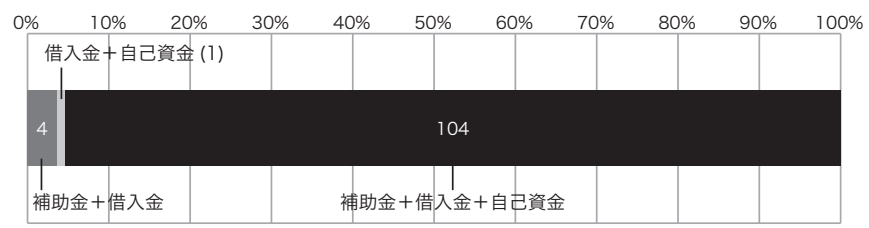

図 15 建設費 + 土地取得費の資金調達状況 $(n=109)$

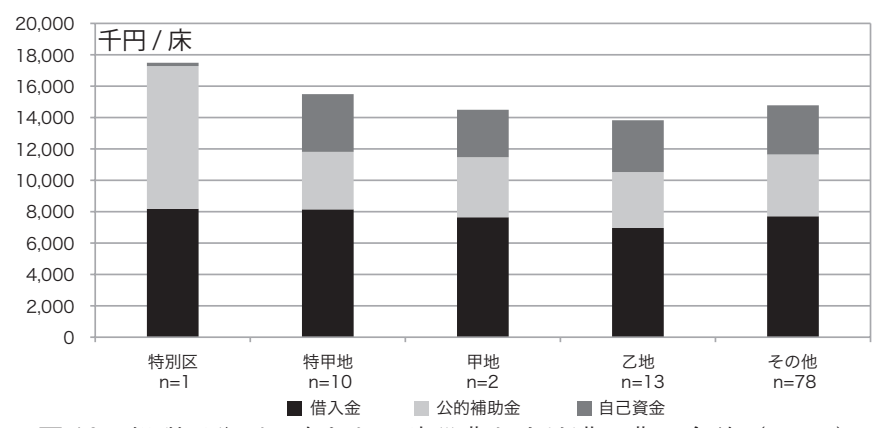

図 16 報酬区分別一床あたり建設費と土地購入費の合計 $(\mathrm{n}=104)$ 
状況と費用について考察したが、ここでは、建設費、土地購入費を 合わせた初期費用の動向について考察する。建設費、土地取得費い ずれについても資金調達の内訳の記載のあった 125 施設を対象とし た。図 15 に、資金調達の状況を示寸。自己資金、借入金、公的補助 金全てを利用している施設が $95.4 \%$ とほとんどである。

\section{（2）報酬区分別一床あたり建設費および土地購入費とその内訳}

図 16 に、自己資金、借入金、公的補助金の全てを利用している 104 施設の一床あたりの建設費と土地購入費の合計とその内訳を報酬 区分別に示寸。全体の平均は、14, 749 千円 / 床であった。総額につ いては、 1 事例のみであるが特別区が最も高く 17,491 千円/床であり、 乙地が最も低くなっている。特別区の 1 事例はほとんどの資金を借 入金と公的補助金でまかなっており、若干公的補助金の比率が大き い。これは、東京都の土地購入に対する補助の影響も大きいと考え られる。他の地域では半分以上を借入金が占めている。平均の借入 金額は、7,660千円/床であった。

\section{（3）小結}

建設費と土地購入費をあわせた資金調達状況では、自己資金、借 入金、公的補助金の全てを利用している施設が大半を占め、土地取 得から始めて建物を建設して開設するには、公的補助金、借入金両 方を利用する必要がある。さらにその内訳をみると、報酬地域区分 にかかわらず借入金の割合が高い。特別区では、自治体が土地に対 して補助をおこなうことで施設開設が可能になっている。

\section{4. 結論}

本研究では、一般的なユニット型特養の建設費、土地購入費の実 態を明らかにすることを目的とし、分析をおこなった。以下に明ら かになったことをまとめる。

単位あたり面積および建設費として、平均值は、一床あたり面積 では $53.98 \mathrm{~m}^{2}$ / 床、面積あたり建設費では、239.22 千円 / $\mathrm{m}^{2} 、$ 一床 あたり建設費で 12,962 千円/床であり、一床あたり面積および面積 あたり建設費の変動係数は大きな差はみられなかった。エリア区分 別では、一床あたりの面積は、関東、近畿で $50 \mathrm{~m}^{2} /$ 床以下と特に小 さく、それ以外のエリアの方が理論上縮減が可能であると考えられ る。経年変化をみると、公的補助金が潤沢であった 2003 年が最も高 くそれ以降はいずれも減少の様子がみられた。一床あたり建設費は、 エリア区分別では面積あたり建設費の、建設年別では一床あたり面 積の影響が強くみられた。床面積の最低基準が $10.65 \mathrm{~m}^{2} に$ 緩和され たため、今後はその影響で一床あたり建設費も減少することが推察 される。

建設費の資金調達では、公的補助金、自己資金、借入金の全てを 併用する施設が最も多かった。建設費の平均值は 12,687 千円 / 床で あり、 $57.9 \%$ を借入金が占めている。公的補助金は 2005 年以降減少 しており、その分借入金が増加している。自己資金額は法人開設年 数に相関がみられた。

土地取得には、購入と貨貸が考えられるが、 $66.1 \%$ が購入しており、 賃貸より多い。市街化区域では、他の地域に比べ購入の割合が低いが、 東京 23 区にあたる特別区では全ての施設が購入で取得しており、東 京都による補助金の影響が考えられる。購入に限ると自己資金のみ
で取得している施設が最も多く、借入金と併用している施設が次い で多い。購入金額の平均値は、特別区、市街化区域はその他の地域 に比べ、 $2 \sim 3$ 倍近く高い。

建設費と土地購入費をあわせると、95.4\%の施設が、公的補助金、 借入金、自己資金の全てを併用しており、土地取得から始めて建物 を建設して開設するには、公的補助金、借入金両方を利用する必要 があることがわかった。報酬地域区分に関わらず、借入金の割合は 高く、開設後の経営からみると、いかに借入金を縮減させるかが重 要となる。

\section{今後の課題}

本稿では、ユニット型特養の建設費と土地取得費の実態について 考察をおこなった。定員等との関係についても分析をおこなったが、 顕著な傾向を見ることはできなかった。今後は、定員、構造等と建 設費の関係を明らかにすることも課題としたい。また、必要な施設 整備をおこないつつ、借入金を減少させ、費用を削減することのみ に終始することは好ましくない。より適切な建設費とするためには、 居住性と建設費の関係性について明らかにする必要があり、今後の 課題としたい。

本研究は、認知症介護研究・研修東京センターユニットケア推進 室（現、日本ユニットケア推進センター）により、平成 21 年度老人 保健健康増進等事業としておこなわれた研究の一部を元に分析をお こなった。

\section{注}

注 1）文献 1 、用語の定義より。

注 2）国庫補助金は、地方財政法第 16 条に「国は、その施策を行うため特別 の必要があると認めるとき又は地方公共団体の財政上特別の必要がある と認める時に限り、当該地方公共団体に対して、補助金を交付すること ができる」と示されており、国の裁量権が強い。一方、交付金は地方自 治体が策定する整備計画に対し、国で採択指標に基づく評価をおこない、 評価の高い順に予算の範囲内で交付される。

注 3）文献 2 に、基準の改正が報告されている。

注 4）現在、居住費は全国一律で、多床室は月額約 1 万円、ユニット型個室は 月額約 6 万円となっており、一部の低所得者（生活保護受給者ならびに 本人非課税世帯）に対しては負担軽隇措置が講じられており、生活保護 受給者は社会福祉法人による減免により個室利用が可能となっている。 また、平成 24 年度介護報酬改定では、第 3 段階入所者の負担限度額の 見直しがおこなわれ、減額されることが決定している。

注 5）文献 3 に、平成 24 年度介護報酬改定の内容が示されている。

注 6）報告書では協会が発行する「保健・医療・福祉施設建築情報シート集」 に揭載された 1998 ～ 2008 年に竣工した物件を対象としている。

注 7）アンケート調查は、認知症介護研究・研修東京センターユニットケア推 進室（現、日本ユニットケア推進センター）が実施し、センターがおこ なうユニットケア研修を 2008 年度までに受講した 3,344 施設を対象と した。なお、ユニット型を整備したほとんどの施設が、センターが開催 する職員研修を受講しており、初期の研究には従来型でユニットケアを 志向する施設も含まれている。

注 8) 回収した 1, 008 施設のうち、特別養護老人ホーム 871 施設、介護老人保 健施設 55 施設、療養型介護保険施設 2 施設、単独短期入所施設 65 施設、 無回答15施設であった。今回の分析では、特養のみを対象とし、抽出した。

注 9）文献8では、79 施設を対象とし、1 床あたり延床面積の平均は $51.6 \mathrm{~m}^{2} 、$ $35 \mathrm{~m}^{2} /$ 床以下の施設は 1 施設の夕報告されている。文献 16 の福祉医療 機構データの分析では、115 施設を対象とし、1 床あたり延床面積の平 均は $54.7 \mathrm{~m}^{2} /$ 床、 $35 \mathrm{~m}^{2} /$ 床未満の施設はみられない。 
注 10) 特別養護老人ホームでは、土地に関わる費用を取得費とその後の造成を 分けて考える場合が多く、その場合、造成費は建設費と一緒に考えた方 がなじみ易いため、今回は土地取得費とさらに器具及び備品調達費を含 んだ金額を分析の対象とした。

注 11) 調查時点（2009 年度）での報酬地域区分（特別区、特甲地、甲地、乙地、 その他の 5 区分）であり、2012 年 4 月からは 7 区分に細分化されること が決定している。

注 12) 文献 1 。厚生労働省の平成 21 年度の介護老人福祉施設の調查では、介護 老人福祉施設 6,127 施設のうち 5,876 施設から回答があり、そのうち定 員が 30 〜 59 人が $44.5 \% 、 60$ 〜 79 人が $16.5 \% 、 80$ 〜 99 人が $21.8 \% 、 100$ 〜 119 人が $12.2 \% 、 120$ 人以上が $4.9 \%$ であった。また、2006 年に制度化 された定員が 29 名以下の地域密着型介護老人福祉施設は 257 施設であ り、介護老人福祉施設の中では、 $4.03 \%$ を占める。

注 13) 独立行政法人福祉医療機構は、平成 15 年 10 月設立、福祉医療の基盤整 備を進めるため、社会福祉施設等の整備のための貸付事業をおこなって おり、施設整備をおこなうほとんどの施設が機構から借入れている。ま た、機構から借入した特養の経営状態については公表されており、今回 はこのデータを用いた。

注 14) 現在、東京都では、「定期借地権利用による整備促進特別対策事業」と して、用地確保のための定期借地権設定に際して土地所有者に支払われ た一時金の一部について、平成 21 年 5 月 29 年以降、平成 23 年度まで の契約および一時金の支出に対して、補助をおこなっている。

\section{参考文献}

1）厚生労働省 : 平成 21 年度介護サービス施設・事業所調查結果の概況

2）独立行政法人国立印刷局：官報第 5407 号，平成 22 年 9 月 30 日

3）厚生労働省：第 88 社会保障審議会介護給付費分科会資料，平成 24 年 1 月 25 日

4）橘弘志, 外山義, 高橋鷹志, 古賀紀江 : 個室型特別養護老人ホームにおけ る個室内の個人的領域形成に関する研究, 日本建築学会計画系論文集, 第 500 号，pp133-138，1997.10

5）井上由起子, 外山義, 小滝一正, 大原一興 : 高齢者居住施設における入 居者の個人的領域形成に関する考察 住まいとしての特別養護老人ホーム のあり方に関する研究 その 1 , 日本建築学会計画系論文集, 第 501 号, pp109-115，1997. 11

6) 橘弘志, 外山義, 高橋鷹志 : 特別養護老人ホーム入居者の個人的領域形成 と施設空間構成 個室型特別養護老人ホームの空間構成に関する研究 そ の 2, 日本建築学会計画系論文集，第 523 号，pp163-169，1999.9

7）井上由起子, 外山義, 小滝一正, 大原一興 : 高齢者居住施設における個別 的介護に関する考察 住まいとしての特別養護老人ホームのあり方に関す る研究その 2, 日本建築学会計画系論文集，第 508 号，pp83-89，1998. 6

8）毛利志保, 井上由起子, 谷口元: 小規模生活単位型特別養護老人ホームに おけるケア体制を踏まえた空間特性に関する研究, 日本建築学会計画系論 文集 第 572 号，pp. 41-47，2003.10

9）董恩伯，毛利志保，谷口元，井上由起子 : 制度化以降の平面計画の動向 及びケア体制との関わりについてーユニット型特別養護老人ホームの建築計 画に関する研究 その 1 , 日本建築学会計画系論文集 第 649 号, pp. 569$577,2010.3$

10)橘弘志 : 特別養護老人ホームのケア環境と入居者の生活展開の比較一個室型 特別養護老人ホームの空間構成に関寸る研究 その 3 , 日本建築学会計画 系論文集 第548 号，pp. 137-144，2001.10

11) 松原茂樹，足立啓，植野知津子，舟橋國男，览玉桂子：入居者に対する 介護職員の関わりに関する考察：ユニットケア型高齢者福祉施設におけ る介護職員のケアのあり方に関する研究，日本建築学会計画系論文集 第 561 号，pp. 137-144，2002.11

12)石井敏 : ユニット型特別養護老人ホームの夜勤介護における行為と空間 滞在の分析, 日本建築学会計画系論文集 第656号, pp. 2315-2324, 2010. 10

13)毛利志保，秋葉都子：ユニットケア型介護保険保険施設におけるコニット リーダーの実態と課題，介護経営，第 2 巻 第 1 号, pp. 21-34, 2007.11

14) 井上由起子：個室面積緩和措置による建設費削減効果を用いた低所得者負 担軽減策についての一考察-特別養護老人ホームにおける個室 (ユニット型)
と多床室（従来型）の比較検討-, 介護経営，第 6 巻 第 1 号, pp. 67-77, 2011. 11

15)藤井賢一郎，柿本貴之，白石旬子：介護老人福祉施設の財務之「再生 産コスト」に関する基䃈研究, 介護経営, 第 5 巻 第 1 号, pp. 26-38, 2010. 11

16）日本医療福祉建築協会：高齡者施設における建物整備と法人経営一質を担保 しつつ建物費用を抑制する手法に関する研究，2009.3

17)認知症介護研究・研修東京センター: 経年変化を踏まえたユニット型施設 の運営実態と地域におけるユニットケアの啓発に関する調査研究事業報告 書, 2010.3

18) 建築思潮研究所編：建築設計資料 103 ユニットケアー特別養護老人ホーム・ 介護老人保健施設・他，建築資料研究社，2005

（2012年 2 月 8 日原稿受理， 2012 年 7 月17日採用決定） 